San Jose State University

SJSU ScholarWorks

Faculty Publications

$1-1-2010$

\title{
Teaching English language learner students in US mainstream schools: Intersections of language, pedagogy, and power
}

Katya A. Karathanos

San Jose State University, katya.aguilar@sjsu.edu

Follow this and additional works at: https://scholarworks.sjsu.edu/second_ed_pub

Part of the Secondary Education and Teaching Commons

\section{Recommended Citation}

Katya A. Karathanos. "Teaching English language learner students in US mainstream schools:

Intersections of language, pedagogy, and power" International Journal of Inclusive Education (2010):

49-65. https://doi.org/10.1080/13603110802504127

This Article is brought to you for free and open access by SJSU ScholarWorks. It has been accepted for inclusion in Faculty Publications by an authorized administrator of SJSU ScholarWorks. For more information, please contact scholarworks@sjsu.edu. 
Teaching English language learner students in US mainstream schools:

Intersections of language, pedagogy, and power

Katya Karathanos $^{\mathrm{a}}$

a Department of Secondary Education, Connie L. Lurie College of Education, San Jose State University, San Jose, CA, USA. Email: kkaratha@email.sjsu.edu 
Abstract

This study explored to what extent two groups of mainstream teachers in the midwestern region of the USA with differing degrees of English Language Learner (ELL)-specific university preparation reportedly engaged in practises that incorporated the native languages (L1) of ELL students in instruction. The study further examined specific strategies reported by mainstream teachers in promoting L1 use in instruction as well as challenges identified in implementing this practise. The study utilized a mixed-method design that included analyses of survey data from a quantitative study ( $n=227)$ and qualitative analyses of teacher discourse from course documents and open-ended survey questions. Findings indicated that while both groups of teachers reportedly engaged in practises that promoted L1 use in instruction to some extent, teachers with at least three courses of ELL-specific university preparation appeared to engage in these practises to a much greater extent than those without such preparation. This paper explores the implications of results from this study for teacher education programmes in the USA with the responsibility of preparing teachers to effectively serve growing numbers of culturally and linguistically diverse student populations.

Keywords: Teacher practices; English language learners; Mainstream; Native language

\section{Introduction}

In the USA, public school teachers are currently experiencing dramatic increases in the number of English language learner (ELL) students with whom they work. From 1995-2005, the enrollment of ELL students in public schools across the USA grew more than $60 \%$, while the 
general school population increased less than 3\% (National Clearinghouse for English Language Acquisition [NCELA], 2005). Projections indicate this trend will continue, with ELL students comprising an estimated 40\% of the K-12 population in the nation by the year 2030 (Kindler, 2002). Yet, the diverse needs of a significant number of ELL students remain unmet as many of the teachers who serve these students lack the preparation and skills necessary to effectively serve them. For instance, only about 2.5\% of teachers in the USA who teach ELL students hold a degree in either bilingual or English as a second language (ESL) education (McClosky, 2002). Additionally, as many as $45 \%$ of K-12 teachers in the country have ELL students in their classrooms, while only $12 \%$ of teachers across the nation have been provided even modest preparation to address the academic, linguistic and psychosocial needs of these students (McClosky, 2002).

The increase in the number of ELL students in the USA can, in significant part, be attributed to large waves of immigration within the past decade. From 2000-2007, more than 10.3 million immigrants have arrived in the country, making this the highest seven year period of immigration in US history (Camarota, 2007). Morover, immigrants now account for one in eight US residents, the highest level in 80 years (Camarota, 2007). While immigrant populations have historically centered mostly in coastal areas of the USA, these patterns have begun to shift, with immigrants migrating to other areas of the country including regions in the Midwest. Over the past several years, for instance, a number of states in the Midwest have experienced increases in ELL student enrollment that have exceeded 200\% per annum (NCELA, 2005). These states, with little history of serving ELL student populations, often lack teachers with adequate preparation and training to address the educational needs of culturally and linguistically diverse students. 
Currently, the most common programme model serving ELL students in US schools is the 'pull-out' model. With this type of programming, students generally spend the majority of their school day in the mainstream classroom with native English-speaking peers and teachers. At some point during the school day, they are pulled out of the classroom for ESL-specific instruction for anywhere from one half hour to two hours a day (Berube, 2000). Consequently, the majority of the responsibility of educating ELL students falls on the grade-level mainstream teacher. This has major implications for these teachers who not only must link core academic instruction to national and state content standards, but must also ensure that curriculum and teaching strategies for ELL students are aligned with English language proficiency standards (Northwest Regional Educational Laboratory, 2003). Thus, it is imperative that mainstream teachers have a solid understanding of principles and strategies that have been shown to be successful in educating ELL students.

Researchers have emphasized that a critical instructional strategy for teachers to employ in promoting the school success of ELL students is utilization and support of students' native languages in classroom practises. Jim Cummins’ (1981, 1991) Interdependence principle identifies a common underlying proficiency in which cognitive/academic and literacy related skills transfer across languages. According to this theory, instruction in the L1 provides the comprehensible input ELL students need to develop academic concepts. Once a concept or skill is learned in the first language, it will transfer to the second language. Numerous studies have further demonstrated that use of the L1 in the instruction of ELLs is integral to advancing their academic, cognitive, and linguistic development in both the first and second languages (Greene, 1998; Krashen, 1996; Thomas \& Collier, 1997, 2002; Willig, 1985). In their longitudinal study on school effectiveness for ELL students, for instance, Thomas and Collier (1997) concluded 
that native language support 'explains the most variance in student achievement and is the most powerful influence on [ELL] students’ long-term academic success’' (p. 67).

Not only does promoting use of the native language serve as a pedagogical tool that allows ELL students greater access to academic content and the ability to draw on previously acquired skills and knowledge, but this practise also has important psychosocial benefits for students. When teachers incorporate L1 use in the classroom, it confers status and empowers ELL students (Fay, 2004; Lessow-Hurley, 2003). When the native languages of students are valued and capitalized upon, their language is given a status comparable to that of the dominant language and the cultural and personal identities they bring to the classroom are affirmed (Cummins, 2000; Delpit, 2002). When the student's L1 is placed in high esteem, the student's own selfesteem is likely to improve. Use of ELL students' native languages can also increase their motivation and success in school by reducing the degree of culture and language shock they are facing (Aurbach, 1993).

In addition to numerous studies highlighting the importance of L1 use in the instruction of ELLs, the Standards for the English Language Arts, put forth by the International Reading Association and National Council of Teachers of English in 1996, explicitly focus on the need for this practise. Two of the twelve standards directly relate to ELL student issues with one focusing on the importance of native language development, and the other promoting an understanding of and respect for diversity in language use. Moreover, the Position Statement on Native Language Support in the Acquisition of English as a Second Language (1999) put forth by Teachers of English to Speakers of Other Languages (TESOL), maintains that the most effective environments for second language teaching and learning are those that promote ELL 
students' native language and literacy development as a foundation for English language and academic development.

Yet, despite the strong emphasis in the professional literature on the critical role that promoting native language use among ELL students plays in facilitating their school success, little attention has been given to teacher practises relevant to this issue in the mainstream setting. While a growing number of studies have been conducted related to mainstream teachers' attitudes toward ELL student inclusion in the regular education classroom and their perceptions about language diversity issues (Claire, 1995; Griego, 2002; Mantero \& McVicker, 2006; Reeves, 2002; Walker, Shafer, \& Liams, 2004; Youngs \& Youngs), only a handful of studies have focused largely on teachers' practises concerning L1 use in mainstream settings (Freeman \& Freeman, 1993; Goldstein, 2003; Lucas \& Katz, 1994; Tikunoff, Ward, van Broekehuizen, et al, 1991).

The few studies that have been conducted relative to this issue have shown that in US schools and classrooms in which English is the principal language of instruction, there are multiple ways for mainstream teachers to facilitate native language use among their ELL students to promote school success. Yet, the reality is that that the majority of mainstream learning environments in the USA continue to emphasize English immersion, where instruction and learning occur only in English. With the ever-increasing number of ELL student populations in English-dominant settings, further exploration into mainstream teachers' behaviors related explicitly to the inclusion of ELL students' native languages in school and classroom practises is clearly needed.

\section{Purpose}


The majority of public school teachers in the midwestern region of the USA who currently serve ELL students in their classrooms include mainstream teachers with little or no preparation in addressing the educational needs of these students (American Association of Employment in Education, 2001). A key instructional practise for teachers to implement in furthering the academic success of ELL students includes incorporating use of students' native languages in instruction. Yet, little is known about the behaviours of these teachers regarding this practise and how specific teacher preparation in addressing the needs of ELL students is associated with these behaviours. Thus, the purpose of this study was to examine the following questions:

1) To what extent do two groups of mainstream teachers with differing degrees of ELLspecific teacher preparation reportedly promote use of ELL students' native languages in instruction?

2) In what specific ways do mainstream teachers report promoting use of ELL students' native languages in instruction?

3) What do mainstream teachers report as most challenging about this practice?

\section{Methods}

\section{Teachers and Context}

During the ten years between the 1993-94 and 2003-04 school years, the state of Kansas experienced a 269 percent increase in ELL students attending PK-12 schools (National Clearinghouse for English Language Acquisition [NCELA], 2004). The majority of ELL students in Kansas (81\%) speak Spanish as a primary language (NCELA, 2002), with the second and third largest language groups constituting much smaller percentages of the ELL population 
(Vietnamese $=4 \%$ and Laotian $=2 \%$ ). Projections indicate that significant growth of the ELL student population in this state is expected to continue (Kindler, 2002).

Teachers were selected for this study using a purposive sampling method (Krathwol, 1997). Participants included 227 mainstream teachers who either had served or likely would be serving ELL students in the midwestern region of the USA. Teachers were recruited for the study through an ESL endorsement distance education programme offered by a large midwestern public university. The endorsement programme consisted of five graduate-level courses (three credit hours each) aligned with TESOL/NCATE standards (Teachers of English to Speakers of Other Language, 2001) and Guiding Principles for Best Practise with CLD students (Center for Equity and Excellence in Education, 1996). Teachers who were just beginning the programme (who had not taken any previous ELL-specific university courses) as well those near completion of the programme (who had taken at least three courses) were included in the study.

An overarching goal of the university's ESL endorsement programme was to guide teachers in examining and implementing theory and research-based methods specific to promoting the school success of ELL students. A central strand embedded in each of the courses was an emphasis on the role of ELL students' native languages in promoting academic, linguistic, cognitive, and psychosocial development. A second key component threaded throughout program courses was a critical reflection journaling process. During this process, teachers were challenged to reflect upon how their own beliefs, assumptions, and socialization influenced their perspectives and practises related to language diversity, language development, and the education of ELL students. Each course required participants to complete three to five critical reflection journals that were based either on course readings or incidents/events that experienced by teachers relevant to course topics and content. 


\section{Data Collection}

This study utilized a mixed-method approach which inlcluded quantitative analyses of the author’s (author, 2005) dissertation research (based on a large-scale survey) and qualitative analyses of open-ended questions from the survey and teacher course documents. Use of course documents in addition to the survey not only enabled triangulation across methods of data collection, but the documents also provided 'a rich source of information, contextually relevant and grounded in the contexts they represent' (Lincoln \& Guba, 1985, p. 277).

\section{Survey}

The survey from which data was drawn explored pre-service and in-service mainstream teachers' conceptual knowledge, beliefs, and self-reported practises related to language diversity issues. The survey instrument was initially piloted with 19 mainstream teachers from the same university from which the study population was drawn. Surveys used in the study were distributed either by the author (a former instructor for the ESL emdorsement programme), or by other course instructors, at on-site opening sessions for the ESL programme in the fall of 2004. The survey return rate was $97 \%$.

For the present study, the author analysed items from the survey specific to in-service teachers and their self-reported practises related to L1 use in classroom practises $(n=227)$. The survey included three sections: A, B, and C. Data from Section A was not reported in this study as it included items designated for pre-service teachers and items related to knowledge and beliefs (which were not focuses of this study). Rather, data for this study were drawn from Sections B and C of the survey. Section B consisted of questions intended to elicit information about teachers' instructional grade-levels, gender, years of teaching experience, native language, 
second language proficiency, ESL-specific preparation, and degree of experience with ELL students in their classes.

Section C of the survey was intended to explore mainstream teachers' self-reported practises on promoting native language use in instruction with ELL students as well as teachers' perceived challenges related to these practises. After a thorough review of the professional literature, the author was unable to find any published surveys or other instruments that specifically addressed practises of mainstream teachers with regard to incorporation of the native language in instruction. Therefore, the author developed items for Section C of the survey based on current research regarding related instructional practises (Freeman \& Freeman, 1993, 2001; Lucas \& Katz, 1994; Tikunoff, et. al., 1991) as well as her own experiences as a teacher educator working with mainstream teachers who serve ELL students.

The first two items in Section C of the survey elicited information about the percentage of ELL students that teachers had in their classrooms during the previous school year as well as the average number of ELL students teachers had in their classrooms each year for the previous five years. The next five items included 'I' statements describing practises related to promoting native language use in instruction with ELL students. Teachers were asked to respond to these statements by indicating to what degree the statements were descriptive of their practises with ELL students: 1 = seldom or never, 2 = some of the time, or 3 = most or all of the time (see table 1). The last two items in this section were open-ended questions exploring specific strategies as well as challenges reported by teachers related to this practise.

[Insert table 1 about here] 


\section{Course documents}

Course documents analyzed in this study included 160 critical reflection journals and 12 course projects from teachers who were enrolled in the ESL programme's Linguistics course. Projects entailed group action research related to issues of literacy development among ELL students that teachers were required to conduct as part of their coursework. Of the course documents collected, those that included written teacher discourse or artifacts (e.g. lesson materials, parental newletters, photographs of activities, etc.) which referenced, discussed, or provided examples of the use of ELL students' native languages in classroom practises were flagged and selected for further analysis.

\section{Data Analyses}

Survey data were analysed descriptively and inferentially. First, in order to better understand and describe the participants, frequencies and percentages of teachers were calculated relevant to survey items eliciting demographic information. Second, in order to determine to what extent two groups of teachers with varying degrees of ELL preparation reported promoting L1 use in instructional practises with ELL students, frequencies and percentages for each group were computed on the five instructional behaviour items.

Finally, with the aim of exploring specific ways teachers reportedly incorporated L1 use in classroom practises, as well as what challenges they perceived in implementing these strategies, teacher discourse from the two open-ended survey questions and discourse from course documents were examined and coded for emerging themes. After establishing provisional data categories, initial codes were re-examined and refined as data analysis continued and themes were identified (Lincoln \& Guba, 1985). 


\section{Results}

\section{Teacher demographics}

Of the 227 teachers included in the study, just over half (52\%) had not completed any ESLspecific university courses while just under half (48\%) had completed at least three courses (9 credit hours). Fifty-eight percent of teachers indicated they taught at the elementary level, 39\% at the secondary level, and 3\% reported they taught K-12 or 'other'. The overwhelming majority of teachers (81\%) were female and all but four teachers reported that English was their native language. The majority of teachers (66\%) indicated they did not speak a language other than English. For those who did indicate speaking another language, 61\% reported a beginning level of proficiency in the second language, 30\% an intermediate level, and 6\% an advanced level.

The largest number of teachers surveyed (43\%) had 10 or more years of teaching experience. While there were a considerable number of teachers (21\%) with 2-5 years of experience and 5-10 years of experience (23\%), there were also a fraction of teachers (11\%) new to the profession that had been teaching for less than two years. Four teachers did not report the number of years they had been teaching.

A large majority of experienced teachers (82\%) reported having had ELL students in class before. Seventeen percent of teachers reported never having an ELL student in class. Although most teachers had experience with ELL students, many of these teachers reported having a minimal number of ELL students in their classes: Thirty-four percent of teachers reported that 1$5 \%$ of their students in the previous year were ELL and $36 \%$ reported that $1-5 \%$ of their students

in the past five years were ELL. Ranges of ELL student percentages for the previous year and previous five years reported by the other two-thirds of teachers varied considerably. 


\section{Teacher Instructional Behaviours}

In reporting results for each teacher group on instructional behaviour items, teachers who had completed at least three courses of ESL-specific university courses are referred to as $C$-ESL and teachers who had not completed any ESL-specific courses are referred to as the No-ESL group. Discussion is based on valid percentages of teachers who had taught ELL students and responded to items in Section $\mathrm{C}$ of the survey.

Similar percentages of C-ESL teachers (41.8\%) and No-ESL teachers (41.0\%) reported allowing ELL students to use their native languages in their classrooms at least some of the time; yet, considerably more C-ESL teachers (53.6\%) than No-ESL teachers (19\%) reported allowing this practise most or all of the time. Additionally, a large number of C-ESL teachers reported locating native language resources such as curricula, books, articles etc. for ELL students relating to topics of instruction some of the time (60.9\%) or most or all of the time (23.6\%). On the other hand, these percentages were noticeably lower for No-ESL teachers, with 31.6\% reporting this practise some of the time and $11.1 \%$ most or all of the time. Also, while C-ESL teachers generally reported encouraging ELL students to answer questions or write their assignments in the native language some of the time (40\%) or most/all of the time (26\%), this practise was reported to a lesser extent by No-ESL teachers (some of the time $=24.8 \%$; most or all of the time $=4.3 \%)$.

Moreover, while nearly all C-ESL teachers reported pairing or grouping ELL students with the same native languages but differing levels of English proficiency either some of the time (46.2\%) or most/all of the time (50.0\%), 52.6\% of No-ESL teachers reported engaging in this practise some of the time and less than a quarter (23.7\%.) reported utilizing these grouping strategies most or all of the time. On the fifth item, both groups indicated they utilized the 
services of parents, aides, or volunteers fluent in the native languages of their ELL students to assist in explaining content-area material at least some of the time and both groups reported engaging in these practises some of the time to comparable degrees (No-ESL $=39.7 \%$; C-ESL $=$ 38.1\%). A large percentage of teachers from the No-ESL group (41\%) and approximately half of C-ESL teachers (49.5\%) futher reported engaging in this practise most or all of the time.

In sum, while both groups of teachers reportedly engaged in instructional practises that promote use of their ELL students' native languages to some extent, teachers with at least three courses of ELL-specific university preparation appeared to engage in these practises to a noticeably greater extent than teachers without such preparation.

\section{Strategies for promoting use of the $\mathrm{L1}$ in classroom practises}

The first open-ended question of the survey asked teachers to list specific ways they incorporated use of their ELL students' native languages into classroom practises. Five major themes that emerged relevant to this question from teacher survey responses and course document discourse included the following: translation, peer-grouping, materials, learning activities and status/value 
Translation. A number of teachers indicated that the translation of items such as instructions, content, assignments, newsletters and calendars was a key way of promoting L1 use in instruction. Teachers described a variety of resources including the internet, ELL peers, ELL parents and siblings, and teacher aides that were especially helpful in translating items from English to the native languages of their students. Some teachers indicated that they themselves served as translators when they were familiar with the L1. The following passages include teacher discourse describing how the translation of items was used in their classrooms to the benefit of their ELL students:

- We have our assistant help us translate some key phrases and words to Spanish. We told the entire class that we would be taking an 'examen.' As soon as the word was written on the board, our second language learners came to life.

- Students were given a worksheet that contained ... words to be defined and a questions concerning characteristics of a healthy teen. The worksheet was written in English with key words also written in Spanish. The ELL students were shown which textbook had a 'glossario' and were told that they could either write their answers in English or Spanish. Once again, they immediately began to complete their worksheets. It was also amazing to us how much more information they wrote down as compared to the regular education students.

Peer grouping. Many teachers commented that the grouping and pairing of ELL peers was another way they promoted L1 use in classroom practises. Teachers described how they paired or grouped ELL students who spoke the same L1 but had different levels of English proficiency to serve as tutors or translators for each other. They further indicated that this type of 
pairing/grouping was also very helpful in clarifying instructions for ELL students. The following excerpt of teacher discourse illustrates this theme:

- There have been numerous times when I've been in a group discussion with some of my Spanish-speaking students. I would pose a question for students to answer. With confusion, students would often say, 'I know how to say it in Spanish.' I then allow them to confer with someone else in the group who is able to help them translate the idea. Sometimes my directions become too complicated in English. Students often refer to one another after directions to explain my directions in Spanish for better understanding.

Materials. Teachers noted a number of ways they utilized native language materials in the instruction of their ELL students. Especially common was the use of visuals such as word walls, labels, posters, and flashcards in both English and the native language. One teacher described the creation of a special ‘Club Leo' for students to buy books in Spanish at a low cost. Other L1 materials reportedly used by teachers included manipulatives, tapes, CD's, and movies. In the passage below, one mainstream teacher describes the experience of implementing a dual language word wall in her classroom:

- [I] introduced the concept of the word wall to the entire class. The wall is located at the front of the classroom and is divided into two parts. One of the sections will be used for Spanish words and the other will have words written in English. Everyone seemed very excited about using this strategy. The regular education students quickly volunteered to place content vocabulary words up. The ELL students were reluctant at first. [However,] once one of them 
bravely came up and wrote one of the words in Spanish, then the remaining students participated.

Learning activities. Teachers shared a number of learning activities they implemented that promoted native language use among their ELL students. Some of these activities included notetaking, read-alouds, singing, and self-selected reading in the L1. Teachers further described the use of story comprehension questions, vocabulary activities, and word problems in the L1 of their students. The following passages include examples of such learning activities shared by teachers in their discourse and artifacts:

- We often, when presenting new vocab, have ELL students share/teach vocab in (the) native language.

- The students were told to write on one side of the index card in Spanish the vocabulary word (ex. Protein). On the opposite of the card they wrote the word in English. The students then cut out pictures, which depicted examples of that word...they could paste the pictures on either side of the card. 
Status/value. Teachers further described instructional practises and activities that conferred status and placed value on the native languages and cultures of their ELL students. Many teachers commented on how they not only encouraged their ELL students to speak in their native languages, but also guided them to teach other students (and the teacher) words/phrases in the L1. Teachers also prompted ELL students and parents to share information about their native languages and cultures. The excerpts from teacher discourse below are representative of this theme:

- I encourage students to teach us relevant things regarding their native language and I attempt to create a safe environment where students do not feel penalized for their native language.

- I....have students read picture books to the class using their native language. The other students think it's neat to hear stories in a different language.

Other teachers described not only how they encouraged ELL students to share their native languages and cultures in classroom activities, but also how this practise gave them insight into the knowledge and skills of their students that may have otherwise gone unnoticed. Below, one teacher describes a new lens through which he and his colleagues began to view their ELL students after encouraging use of their students' native languages:

- The application of native language support...caused us to acquire a greater personal regard for them [ELL students]. By building upon their current level of knowledge, using native language to allow them to expose their thinking and to use what they have already learned we 
communicated - perhaps for the first time in their attendance in regular education classes in America.

\section{Challenges in promoting use of the $\mathrm{L} 1$ in classroom practises}

The second open-ended question in Section C of the survey asked teachers what they found to be most challenging about incorporating use of their students' native languages into instruction. Themes that emerged relevant to this question from survey responses and course document discourse included limited time and resources, issues with peer involvement, the presence of multiple native languages, and lack of proficiency in the L1.

Limited time and resources. The common thread of teachers not having enough time and resources to incorporate L1 use in instruction appeared repeatedly in teacher discourse. Teachers commented on how difficult it was to find materials/resources in their students native languages when they were already pressed for time with their regular lesson plans. They also expressed frustration with lack of funds and support from the school in obtaining L1 resources as well as the limited availability of bilingual aides to assist in their classrooms. One teacher emphasized how she often ended up spending her own money on books in Spanish for her ELL students.

Issues with peer involvement. A number of teachers noted challenges related to peer involvement when trying to promote L1 use in instruction. One difficulty teachers often described was trying to get native English-speakers involved and interested in activities that incorporated the L1 of ELL's, particularly in hearing and appreciating another language. Other challenges teachers emphasized included having to rely on ELL students to translate for their less proficient peers and not knowing whether or not the students were on task when working with each other in 
groups. The following teacher comment is indicative of beliefs expressed by teachers that their students could be off-task when speaking in their native languages:

- I have to admit that I was one of those teachers that believed when [ELL] students talked and laughed during class time that that they were indeed talking about...things other than the subject. It was annoying when I talked and then they started to talk. There were times when they did laugh. How did I react? I glared at them or walked toward them or I have even reprimanded them...

Presence of multiple native languages. Another commonly perceived obstacle to the promotion of L1 use in classroom practises reported by teachers was having a variety of native languages represented in their classes. One teacher commented that while she was comfortable aiding students of Latino ethnicity, it was much more difficult to find L1 support for her Indian and Persian students. Another teacher shared the following related frustration:

- I teach in a school district where multiple languages are spoken. As a computer teacher, I can't find ways to relate their languages to the material. 
Lack of proficiency in the L1. A final theme related to barriers in promoting L1 use in instruction that emerged in teacher discourse included teachers' lack of proficiency in or inability to speak the native languages of their students. Teachers noted not only how this served as a major barrier in incorporating the L1 of their students into instruction, but also how it was a hindrance in overall communication with ELL students and their parents. Some teachers commented that learning more of the L1 would help them better serve and incorporate the languages of their ELL students in classroom practises. One teacher, for example, shared the following:

- I find that not being able to speak Spanish is the most challenging. It would help me so much especially when speaking to parents.

Other teachers appeared to perceive their lack of proficiency in the native languages of their ELL students as an obstacle to communicating with and involving them in classroom activities. The teacher discourse excerpts below are indicative of such perceptions:

- I don’t remember their language well enough. I can’t really talk to them at all, so I can’t ask them to participate.

- Since I don't speak their language, it has been very difficult for me to speak to them pronouncing words that are wrong or that I'm uncomfortable [saying].

\section{Discussion}

The purpose of this study was to gain a better understanding of US mainstream teachers' practises related to promoting use of ELL students' native languages in instruction. This study 
specifically explored to what extent two groups of mainstream teachers with differing degrees of ELL-related university preparation reportedly engaged in these practises. It further examined specific strategies utilized by mainstream teachers in promoting L1 use in instruction as well as what challenges/barriers they faced in implementing this practise. The following includes a summary and discussion of the research findings, followed by a discussion of implications that results from this study have for teacher education programmes in the US faced with the responsibility of preparing teachers to meet the diverse needs of growing numbers of ELL students.

\section{ELL-specific teacher preparation}

Teachers in this study included predominantly English-speaking K-12 teachers with varied years of teaching experience and varied percentages of ELL students in their classrooms. Teachers also fell into two groups regarding ELL-specific teacher preparation: (1) those having taken at least three ELL-specific university courses or (2) those who had not previously taken any ELL-specific university courses. Findings from survey responses on teacher instructional behaviour items indicated that both groups engaged in a number of practises promoting use of students native languages in instruction at least to some extent: Teachers allowed students to use the L1 in their classrooms, located L1 resources for students, encouraged ELL students to answer questions or write assignments in the L1, paired/grouped ELL's with the same native languages but different levels of English proficiency, and utilized the services of parents, aides, or volunteers fluent in the L1 to assist in explaining content-area material.

While both groups of teachers reportedly engaged in the aforementioned practises to some degree, findings clearly indicated that those teachers with ELL-specific university preparation engaged in these practises to a noticeably greater extent than those without such preparation. In 
light of the professional litearature, these findings are not surprising. Research suggests that teachers who lack a basic understanding of second language acquisition principles often hold common misperceptions about issues relevant to the education of ELLs, including native language use and second language acquisition issues (Claire, 1995; Reeves, 2006). Researchers have also concluded that teachers without specific ELL-related preparation may hold less supportive attitudes and practises toward bilingualism or hold negative language stereotypes (Hamayan, 1990; Samway \& McKeon, 2007).

Teachers in the study with ELL-specific preparation had taken extensive coursework that included content and theory related to best practises in the instruction of ELL students. Course content and theory integrated principles highlighting the interdependence between first and second language acquisition, including how cognitive development of the first language transfers to the second language (Cummins, 1981; 1991). Course content also emphasized research demonstrating the importance of the native language in promoting ELL students' academic, linguistic, cognitive, and psychosocial growth.

\section{Promoting L1 use in instructional practises - Strategies and challenges}

Results from this study indicated that many mainstream teachers who currently work with ELL students do indeed incorporate specific strategies that promote use of their students' native languages in classroom practises. Many of the themes that emerged (such as translation, peergrouping, materials, and learning activities) from analyses of data from the open-ended survey items and course documents were consistent with the practises teachers reported engaging in on instructional behaviour items of the survey.

A further significant theme that emerged included how use of ELL students' native languages conferred status and placed value on students' home languages and cultures. This finding has 
particular significance in light of professional literature suggesting that teacher-student microinteractions, particularly in regard to validation of ELL students' native languages and cultures, can either challenge or reinforce existing societal power relations. Researchers contend that how an educator transacts language policy within his or her own classroom can either reinforce or challenge larger societal relations of power (Auerbach, 1993; Cummins, 2000; Varghese \& Stritikus, 2005). For instance, educators who encourage use of the L1 in classroom practises are not only promoting literacy development and academic achievement in both languages, but they are also directly challenging coercive relations of power that have traditionally oppressed minority and underrepresented groups [i.e. English-only movements that subordinate the native languages and cultures of ELLs] (Cummins, 2000). Futhermore, '...acquiring a second language is to some extent contingent on the societally determined values attributed to the L1, which can be either reinforced or challenged inside the classroom' (Auerbach, p. 17). Given current ideologies of 'English only' and assimiliationist perspectives held by many educators in the US, the notion that teachers in mainstream classrooms are challenging these ideologies by valuing and conferring status on the native languages of their students is especially noteworthy.

Predominant themes that emerged among teacher discourse in relation to perceived barriers or challenges in promoting use of students' native languages in instructional practises included limited time and resources, difficulty with peer involvement, the presence of multiple native languages, and a lack of teacher proficiency in the L1. While these are undoubtedly issues with which many teachers contend, research has, nevertheless, demonstrated that predominantly English-speaking teachers, or teachers who do not speak all of the native languages of their students, can, in fact, feasibly incorporate the L1 of students into instruction in their content-area 
classrooms in a variety of purposeful and beneficial ways (Freeman \& Freeman, 1993; Lucas \& Katz, 1994; Nieto, 2008; Tikunoff, et al., 1991).

Research further indicates that concerns often expressed by teachers regarding L1 incorporation in the classroom (such as not being able to speak the L1 themselves or having multiple native languages represented) often have ideological implications relating to how issues of power are embedded in classroom relations (Auerbach, 1993; Reeves, 2006). For instance, Auerbach (1993) maintains that the issue of language choice often boils down to teacher-student roles, with the teacher having the power to either negate or reinforce use of the L1: 'Whether or not we support the use of learners' L1 is not just a pedagogical matter: It is a political one, and the way that we address it in instruction is both a mirror of and a rehearsal for relations of power in the broader society' (p. 10).

Thus, it is quite possible that many of the perceived barriers espoused by teachers in supporting native use among ELL students in classroom practises may be a reflection of their underlying ideological beliefs. Additionally, such perceived barriers could also be attributed to a lack of knowledge about or misperceptions concerning second language acquisition issues and effective instruction for ELLs commonly held among educators (Claire, 1995; Samway \& McKeon, 2007).

\section{Conclusions}

Research not only underscores the importance of teacher practises that promote use of ELL students' native languages in the classroom, but the professional literature further calls for teacher education programmes to provide pre-service and in-service teachers with the preparation necessary to implement this practise. This is reflected in TESOL's Postion Statement on the Preparation of Pre-K-12 Educators for Cultural and Linguistic Diversity (2003) which 
holds that educators should receive specialized training and preparation in the skills necessary to effectively manage culturally and linguistically diverse classrooms. In this statement, TESOL emphasizes that colleges and universities should include coursework designed for mainstream and content-area teachers specific to meeting the needs of ELL students in academic settings. TESOL further posits that such teacher preparation programmes should ensure that all educators understand the roles that language and culture play in learning, the importance of native language support in achieving academic success, and the sociocultural issues ELLs face when dealing with the demands of mainstream education.

Findings from this study suggested that ELL-specific university courses in a teacher education programme were related to an increase in mainstream teachers' practises of promoting L1 use in instruction. These findings, as well as findings highlighting specific strategies utilized by teachers, are of important significance, especially given the current emphasis on the need for teacher education programmes to help teachers develop the understandings and skills necessary to implement such culturally responsive practises. On the other hand, the perceived barriers to promoting this practise identified and discussed at length by teachers in the study signify that much work remains in in this area.

Moreover, researchers suggest that the practise of promoting use of ELL students' native languages in instruction is not only a critical pedagogical issue, but also a political one (Auerbach, 1993; Cummins, 2000). Thus, an important focus for teacher education programmes should be to provide teachers not only with content, theory, and 'hands-on' strategies in effective practises for ELL students, but also to provide opportunities for teachers to critically reflect upon and explore underlying ideologies and assumptions they may hold related to native language use and first and second language development processes. 
Despite the current paucity of research in this area, it is nontheless promising to see the culturally responsive perspectives and practises of many mainstream teachers in the US related to supporting the native languages of their students. The following teacher reflection leaves us with a vivid picture of what a powerful effect positive strides among teachers in the area of native language inclusion can have for both the teacher and student:

- Using...native language techniques is learned most efficiently when you are face to face, eye to eye with a student thirsting for understanding. Intense concentration by [ELL] students as they try to synthesize the modified English... and the halting native language used by teachers can be seen in their eyes. Pupils in their eyes constrict in an effort to focus on the communication. When the curricular message is made clear there is a different look in their eyes, no longer constricted but enlarged and shining with pride as their work product is approved and praised. We assume their eyes sparkle not so much from self satisfaction of learning, although that is part of their delight, but from the teacher's acceptance of them their culture and their language -- by the teacher who to them is a symbolic representation of American society. 


\section{References}

American Association for Employment in Education. (2001) Educator supply and demand in the US. Available online at: www.ubcareers.buffalo.edu/aaee/ (accessed 2 March 2003).

Auerbach, E.R. (1993) Reexamining English only in the ESL classroom, TESOL Quarterly, 27, 9-32.

Camarota, S. (2007) Immigrants in the United States, 2007: A profile of America's foreign born population. Available online at: http://graphics8.nytimes.com/packages/pdf/national/CIS1128ImmigStats.pdf (accessed 7 December 2007).

Carrasquillo, A. \& Rogdriguez, V. (2002) Language minority students in the mainstream classroom ( $\left.2^{\text {nd }} e d.\right)$, (Clevedon, Multilingual Matters Ltd.).

Center for Equity and Excellence in Education. (1996) Promoting excellence: Ensuring academic success for limited English proficient student (Arlington, VA, Author).

Clair, N. (1995) Mainstream classroom teachers and ESL students, TESOL Quarterly, 29, (1) 189-196.

Cummins, J. (1981) The role of primary language development in promoting educational success 
for language minority students, in: California State Department of Education (Ed), Schooling and language minority students: A theoretical framework (Los Angeles, CA, Evaluation, Dissemination, and Assessment Center).

Cummins, J. (1991) Interdependence of first- and second-language proficiency in bilingual children, in: E. Bialystok (Ed) Language processing in bilingual children (Cambridge, Cambridge University Press).

Cummins, J. (2000) Language, power and pedagogy: Bilingual children in the crossfire (Great Britain, Cambrian Printers Ltd.).

Delpit, L. (2002) The skin that we speak: Thoughts on language and culture in the classroom (New York, New Press).

Fay, K. and Whaley, S. (2004) Becoming one community: Reading and writing with English language learners (Maine, Stenhouse).

Freeman, D.E. \& Freeman, Y.S. (2001) Between worlds: Access to second language acquisition (2nd ed.) (Portsmouth, NH, Heinemann).

Goldstein, T. (2003) Teaching and learning in a multilingual school: Choices, risks, and dilemmas (Mahwah, NJ, Lawrence Erlbaum Associates). 
Greene, J.P. (1998) A meta-analysis of the effectiveness of bilingual education. Available online at: http://www.ncela.gwu.edu/pubs/symposia/reading/article5/greene98.html (accessed 23 June 2004).

Griego, T. (2002) Preparing all teachers for linguistic diversity in K-12 Schools. Paper presented at the annual meeting of the American Association of College for Teacher Education (New York, NY).

Hamayan, E.V. (1990) Preparing PES classroom teachers to teach potentially English proficient students. Proceedings of the First Research Symposium on Limited English Proficient student issues, OBEMLA. Available online at: www.ncela.gwu.edu/pubs/symposia/first/preparing-dis.htm (accessed 4 April 2002).

International Reading Association. (1996) Standards for the English Language Arts. Available online at: http://www.reading.org/resources/issues/reports/learning_standards.html (accessed 1 July 2002).

Kindler, A. (2002) Survey of the states' limited English proficient students and available educational programs and services: 1999-2000 summary report (Washington, DC, National Clearinghouse for English Language Acquisition and Language Instruction Educational Programs). Available online at: http://www.ncela.gwu.edu/pubs/reports/ (accessed 23 June 2004). 
Krashen, S. (1996) Under attack: The case against bilingual education (Culver City, CA, Language Education Associates).

Krathwohl, D. (1998) Methods of educational social science research: An integrated Approach (2nd ed.) (New York, Addison Wesley Longman, Inc.).

Lessow-Hurley, J. (2003) Meeting the needs of second language learners: An educator's guide. (Virginia, ASCD).

Lincoln, Y. S. \& Guba, E. G. (1985) Naturalistic inquiry (Newbury Park, CA, Sage).

Lucas, T. \& Katz, A. (1994) Reframing the debate: The roles of native languages in English-only programs for language minority students, TESOL Quarterly, 26 (5), 537-556.

McClosky, M. (2002) President’s message: No child left behind [Electronic version]. TESOL Matters, 12 (4). Available online at: http://www.tesol.org/pubs/articles/2002/tm12-4-04.html (accessed 2 May 2004).

Mantero, M. and McVicker, P. (2006) The impact of Experience and coursework: Perceptions of second language learners in the classroom. Radical Pedagogy, 8, (1). Available online at: http:// radical pedagogy.icaap.org/content/issue8_1/mantero.html (accessed 6 October 2007). 
National Center for English Language Acquisition [NCELA]. (2002) State elementary and secondary LEP enrollment growth and top languages. Available online at: http://www.ncela.gwu.edu/stats/state specific/index.html (accessed 3 February 2004).

NCELA. (2004) Kansas Rate of LEP Growth/1993/1994-2003/2004. Available online at: http:// www. ncela.gwu.edu/policy/states/reports/statedata/2004LEP/Kansas-G-05.pdf (accessed 16 August 2007).

NCELA (2005) The Growing Number of Limited English Proficient Students 1994/95-2004/05. Available online at: August 16, 2007 from http://www.ncela.gwu.edu/policy/states/reports/statedata/2004LEP/GrowingLEP_0405_ Nov06.pdf (accessed 16 August 2007).

Nieto, S. \& Bode, P. (2008). Affirming diversity: The sociopolitical context of multicultural education $\left[5^{\text {th }}\right.$ ed] (Boston, MA, Pearson education, Inc.).

Northwest Regional Educational Laboratory. (2003). Strategies and resources for mainstream teachers of English Language Learners. Available online at http://www.nwrel.org/request/2003may/ell.pdf (accessed 18 December 2006).

Samway, K.D. and McKeon, D. (2007) Myths and Realities: Best Practices for English Language Learners (2nd ed) (Portsmouth, NH, Heinemann). 
Schmidley, A.D. and Robinson, J. G. (2003) Measuring the foreign-born population in the United States with the current population survey: 1994-2002 (Population Division Working Paper Series, No. 73: U.S. Census Bureau). Available online at: http://www.census.gov/population/www/documentation/twps0073.html (accessed 13 August 2007).

Teachers of English to Speakers of Other Languages (TESOL). (1999). Position statement on native language support in the acquisition of English as a second language (ESL). Available online at: http://www.tesol.org/s_tesol/sec_document.asp?CID=32\&DID=382 (accessed 25 June 2006).

TESOL. (2001). TESOL ESL Standards for P-13 teacher education programs. Available online at: www.tesol.org/pdfs/aboutassoc/ncatestds.pdf (accessed 3 March 2003).

TESOL. (2003). Position statement on the preparation of pre-k-12 educators for cultural and linguistic diversity in the United States. Available online at: http://www.tesol. org/s_tesol/ bin.asp?CID= 32 \&DID=1301\&DOC=FILE.PDF (accessed 25 June 2006).

Thomas, W. P., \& Collier, V. P. (1997) School effectiveness for language minority students (NCELA Resource Collection Series, No. 9). Available online at: http://www.ncela.gwu.edu/ncbepubs/resource/effectiveness (accessed 3 July 2003).

Thomas, W. P., and Collier, V. P. (2002) A national study of school effectiveness for language 
minority students' long-term academic achievement (Center for Research on Education, Diversity and Excellence [CREDE]). Available online at: http//www.crede.ucsc.edu/ research/ llaa/ 1.1 _ final.html (accessed 3 July 2003).

Tikunoff, W.J., Ward, B.A., van Broekhuizen, L.D., Romero, M., Vega-Castaneda, L., Lucas, T., \& Katz, A. (1991) Final report: A descriptive study of significant features of exemplary special alternative instructional programs (Los Alamitos, CA, Southwest Regional Laboratory).

Youngs, C. \& Youngs, G. (2001) Predictors of mainstream teacher's attitudes toward ESL students. TESOL Quarterly, 35 (1), 97-118.

Walker, A., Shafer, J., \& Liams, M. (2004) ‘Not in my classroom’: Teacher attitudes towards English language learners in the mainstream classroom. NABE Journal of Research \& Practice, 2 (1), 130-160.

Reeves, J. (2006) Secondary teacher attitudes toward including English language learners in mainstream classrooms, The Journal of Educational Research, 99 (3), 131-142.

Varghese, M. \& Stritikus, T. (2005) 'Nadie me dijo (Nobody told me)’: Language policy negotiation and implications for teacher education. Journal of Teacher Education, 56 (1), 73-87. 
Willig, A. (1985) A meta-analysis of selected studies on the effectiveness of bilingual education, Review of Educational Research, 55, 269-270. 